\section{Sighting of King Cobra Ophiophagus hannah in Sikkim, India: a new altitude record for the northeast}

\author{
T. Bashir ${ }^{1}$, K. Poudyal ${ }^{1}$, T. Bhattacharya ${ }^{1}$, \\ S. Sathyakumar ${ }^{2} \&$ J.B. Subba ${ }^{3}$ \\ 1,2 Wildlife Institute of India, P.O. Box 18, Chandrabani, \\ Dehradun, Uttarakhand 248001, India \\ ${ }^{3}$ Department of Forests, Environment and Wildlife \\ Management, Deorali, Gangtok, Sikkim, India \\ Email: ${ }^{2}$ ssk@wii.gov.in (corresponding author)
}

The King Cobra Ophiophagus hannah, the world's largest venomous snake (grows up to $5.85 \mathrm{~m}$, Aagaard 1924), is rare, but has wide distribution (David \& Vogel 1996). This monotypic genus of the family Elapidae is considered as a species complex by Das (2002), as the species varies in coloration, scalation and body proportion. The King Cobra is distributed in India, Nepal, Bangladesh, Bhutan, Myanmar and most parts of Southeast Asia (David \& Vogel 1996; Selich \& Kestle 2002). In India, it is distributed in the Western Ghats, Shiwalik and terai regions of Uttarakhand and Uttar Pradesh, Bihar, Orissa, West Bengal, northeastern India and the Andaman Islands (Das 2002; Whittaker \& Captain 2004; Ahmed et al. 2009). The King Cobra is listed under Schedule II of the Indian Wildlife (Protection) Act, 1972; Appendix II of CITES; and in the Least Concern category by IUCN (2004). It inhabits thick primary forests and estuarine mangrove swamps with heavy rainfall (Whitaker \& Captain 2004) and has been reported to occupy humid

Date of publication (online): 26 June 2010

Date of publication (print): 26 June 2010

ISSN 0974-7907 (online) | 0974-7893 (print)

Editor: S. Bhupathy

Manuscript details:

Ms \# 02438

Received 08 April 2010

Final received 10 May 2010

Finally accepted 18 June 2010

Citation: Bashir, T., K. Poudyal, T. Bhattacharya, S. Sathyakumar \& J.B Subba (2010). Sighting of King Cobra Ophiophagus hannah in Sikkim, India: a new altitude record for the northeast. Journal of Threatened Taxa 2(6): $990-991$

Copyright: (c) T. Bashir, K. Poudyal, T. Bhattacharya, S. Sathyakumar \& J.B. Subba 2010. Creative Commons Attribution 3.0 Unported License. JoTT allows unrestricted use of this article in any medium for non-profit purposes, reproduction and distribution by providing adequate credit to the authors and the source of publication.

Acknowledgements: We are grateful to the Department of Forests, Environment and Wildlife Management, Government of Sikkim for granting us permission to work in Sikkim. We thank the Wildlife Institute of India, Dehradun for providing us the grants and support

OPEN ACCESS | FREE DOWNLOAD () (1) (1) jungles with thick undergrowth, cool swamps and bamboo clusters (David \& Vogel 1996; Selich \& Kestle 2002; Leviton et al. 2003; Anon 2005; Das et al. 2008). In terms of altitudinal distribution, this species is known to inhabit from $150 \mathrm{~m}$ to $1530 \mathrm{~m}$ in Nepal (Selich \& Kestle 2002), sea level to $1800 \mathrm{~m}$ in Sumatra (David \& Vogel 1996) and has been reported up to $2181 \mathrm{~m}$ in Mussoori Hills in India (Waltner 1975).

In the present paper, we report the sighting of the King Cobra (Image 1) from Yuksam village $\left(27^{\circ} 22^{\prime} 12.5^{\prime \prime} \mathrm{N}\right.$ \& 88 $\left.{ }^{\circ} 13^{\prime 2} 27.0^{\prime \prime} \mathrm{E}\right)$ bordering Khangchendzonga Biosphere Reserve in the West District of Sikkim, India. The snake was observed in a drain adjoining human settlement (altitude: 1820m) on 06 December 2009 at 0805hr. Images 2, 3 \& 4 show various aspects of the snake. It was visually estimated to be about $3-3.5 \mathrm{~m}$ in length with all characteristic features clearly distinct. A few days later, the snake was found to have moved a distance of about $200 \mathrm{~m}$ and taken refuge near Karthok (27022'14.2'N \& 88 ${ }^{\circ} 13^{\prime} 21.2$ "E), a sacred lake at an altitude of $1840 \mathrm{~m}$ and in later days was oftenly seen basking on a rock near bamboo thickets adjoining the lake.

There are two highlights of this sighting viz., the new altitude record of $1840 \mathrm{~m}$ in the entire northeast and the edge of subtropical broadleaved evergreen forest and temperate forests (characterized by the presence of Castanopsis hystrix, Rhododendron arboreum and Symplocos sp. along with bushes of Rubus ellipticus and Edgeworthia gardneri), which may indicate the emergence of a potential habitat for the King Cobra in Sikkim Himalaya, hence needs further study. Prior to this sighting, the species has been reported from Gangtok $1700 \mathrm{~m}$ in 1923 and was believed to be limited to the tropical forests of Sikkim Himalaya $<1250 m$ (Gammie 1928). The species has also been reported from the Teesta Valley, Sikkim at elevations <500m (Chettri \& Bhupathy 2007;

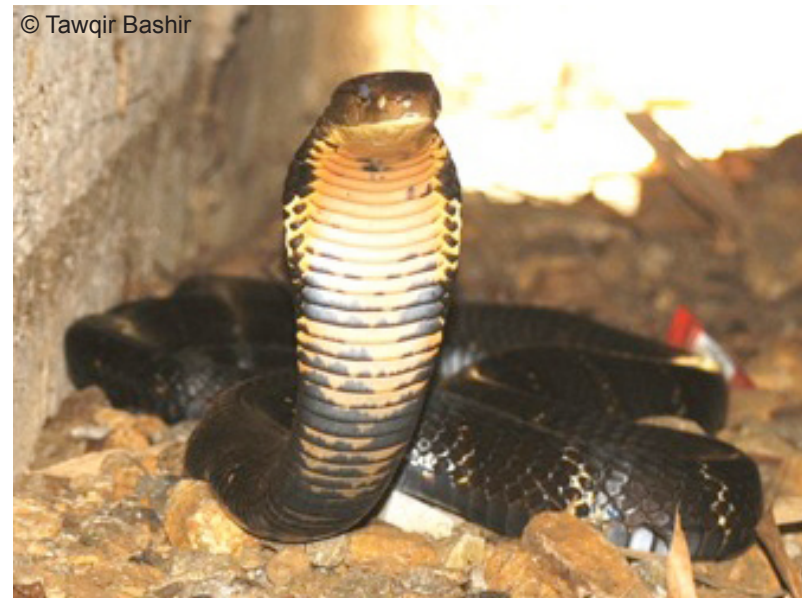

Image 1. The King Cobra sighted in Yuksam, western Sikkim 


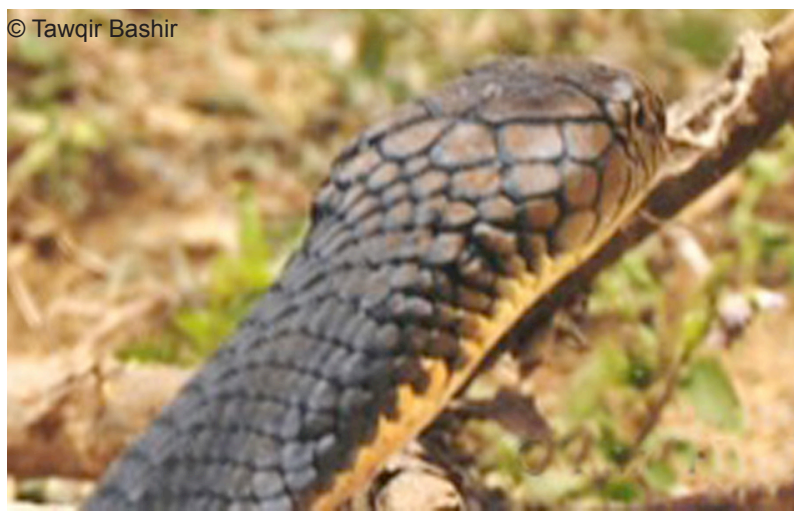

Image 2. Showing the parietal and temporal scales

Chettri et al. 2008). The highest known altitude record for King Cobra in the entire northeastern India was $1700 \mathrm{~m}$ at Khonoma, Nagaland (Das et al. 2008). Temperate forests of the eastern Himalaya have never been reported as a habitat for the King Cobra as they were in higher altitudes characterized by cold climatic conditions (Ahmed et al. 2009).

There have been very few herpetofaunal surveys in this region as evident from the record of the King Cobra after a gap of 82 years from Sikkim (Gammie 1928; Chettri \& Bhupathy 2007; Chettri et al. 2008). Lack of awareness among the local people could also be a disadvantage for the conservation of this species as its status and distribution has not been fully documented. Therefore, we recommend that dedicated surveys be carried out in all four districts of Sikkim to ascertain the present distribution limits and conservation status of the King Cobra and other species of herpetofauna as initiated by Chettri et al. $(2008,2010)$; and awareness programmes for the local communities to enable them understand the significance of this species and conservation importance of other herpetofauna. This new record of King Cobra in temperate forests and at higher altitudes requires further research.

\section{REFERENCES}

Aagaard, C.J. (1924). Cobras and King Cobras. Natural History Bulletin Siam Society 6: 315-316.

Ahmed, M.F., A. Das \& S.K. Dutta (2009). Amphibians and Reptiles of Northeast India. A Photographic Guide. Aaranyak, Guwahati, India, 169pp.

Anonymous (2005). Pit Stop. Newsletter of the Madras Crocodile Bank. 1-2pp. www.madrascrocodilebank.org/SupportFiles/.../Pitstop_Oct_05.pdf

Chettri, B. \& S. Bhupathy (2007). Reptile fauna of Sikkim with emphasis to the Teesta valley. Journal of Hill Research 20(1): $1-6$.

Chettri, B., S. Bhupathy \& B.K. Acharya (2008). Conservation strategy for reptiles along the Teesta Valley, Sikkim. Paper presented at the annual meeting of the International Congress for Conservation Biology, Convention Center, Chattanooga, TN. Online <PDF> http://www.allacademic.com/ meta/p240332_index.html

Chettri, B., S. Bhupathy \& B.K. Acharya (2010). Distribution

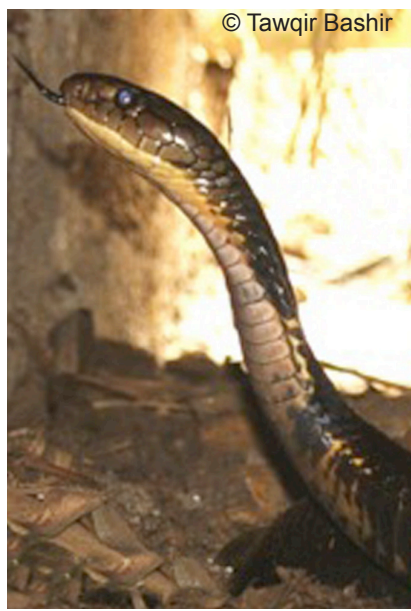

Image 3. Showing the supralabial and ocular scales

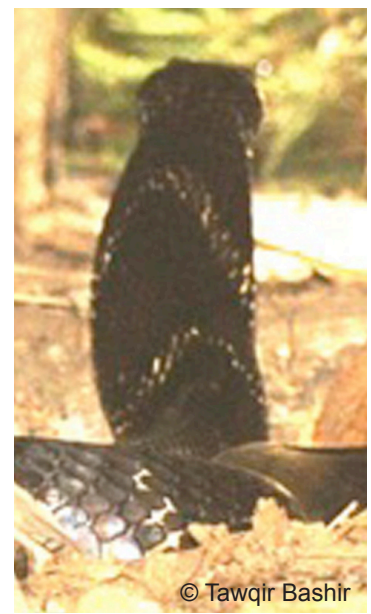

Image 4. Showing distinct $\Lambda$ shaped bands on the hood pattern of reptiles along an eastern Himalayan elevation gradient, India. Acta Oecologica 36(1): 16-22.

Das, I. (2002). A Photographic Guide to Snakes and Other Reptiles of India. New Holland Publishers Ltd., London, UK., 144pp.

Das, A., M.V. Nair, M.F. Ahmed \& P.K. Sharma (2008). Distribution of King Cobra (Ophiophagus hannah) in northeastern India with new altitudinal record and notes on its habitat. Tiger Paper 35(4): 1-6.

David, P. \& G. Vogel (1996). The Snakes of Sumatra: An Annotated Checklist and Key with Natural History Notes. Edition Chimaira, Frankfurt-am-Main, Germany, 260pp.

Gammie, J. (1928). Reptiles, pp.188-190. In: Rishley, H.H. (ed). The Gazetteer of Sikhim. Low price publication, Delhi, 397pp.

IUCN (2004). 2004 IUCN Red List of Threatened Animals. IUCN, Gland, Switzerland and Cambridge, U.K., 448pp.

Leviton, A.E., G.O.U. Wogan, M.S. Koo, G.R. Zug, R.S. Lucas \& J.V. Vindum (2003). The dangerously venomous snakes of Myanmar. Illustrated checklist with keys. Proceedings of the California Academy of Sciences 54(2): 407-462.

Selich, H. \& W. Kästle (eds) (2002). Amphibians and Reptiles of Nepal. Gantner, A.R.G., V.G. Verlag \& Ruggell (distributed by Koeltz, Koenigstein, Germany), 1201pp, 127pls. (including 374 col. figs).

Waltner, R.G. (1975). Geographical and altitudinal distribution of Amphibians and reptiles in the Himalayas - Part IV. Cheetal 16: 12-17.

Whitaker, R. \& A. Captain (2004). Snakes of India, The Field Guide. Draco Books, Chennai, Xiv+481pp.

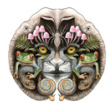

